\title{
Leveraging symbolic capital: the use of blat networks across transnational spaces
}

\author{
PETER RODGERS, ${ }^{*}$ NATALIA VERSHININA, ${ }^{\dagger}$ COLIN C. WILLIAMS \\ AND NICK THEODORAKOPOULOS ${ }^{\S}$
}

*(corresponding author) School of Business, University of Leicester, University Road, Leicester, LE1 7RH, UK

pwr3@leicester.ac.uk

${ }^{\dagger}$ Birmingham Business School, Birmingham University, Edgbaston, Birmingham, B15 2TT, UK

n.a.vershinina@bham.ac.uk

$\star$ Sheffield University Management School, Conduit Road, Sheffield, S10 1FL c.c.williams@sheffield.ac.uk

§Aston Business School, Aston University, Birmingham, B4 7ET, UK n.theodorakopoulos@aston.ac.uk

\begin{abstract}
In this article, we contribute to debates on how social networks sustain migrants' entrepreneurial activities. By reporting on 31 interviews with Eastern European migrants in the UK, we provide a critical lens on the tendency to assume that migrants have ready-made social networks in the host country embedded in co-ethnic communities. We extend this limited perspective by demonstrating how Eastern European migrants working in the UK transform blat social networks, formulated in the cultural and political contours of Soviet society, in their everyday lived experiences. Our findings highlight not only the monetarization of such networks but also the continuing embedded nature of trust existing within these networks, which cut across transnational spaces. We show how forms of social capital based on Russian language use and legacies of a shared Soviet past, are just as important as the role of 'co-ethnics' and 'co-migrants' in facilitating business development. In doing so, we present a more nuanced understanding of the role that symbolic capital plays in migrant entrepreneurial journeys and its multifaceted nature.
\end{abstract}

Keywords BLAT, EASTERN EUROPEAN, ENTREPRENEURSHIP, MIGRATION, TRANSNATIONAL

This is an open access article under the terms of the Creative Commons Attribution License, which permits use, distribution and reproduction in any medium, provided the original work is properly cited. 
In this article, we contribute to the academic debates on the role of social networks in sustaining migrant entrepreneurial journeys. Across the globe, the practice of using personal connections to 'get ahead' and, often, to circumvent formal rules and regulations, remains a common social practice; called wasta in the Arab world (Hutchings and Weir 2006), guanxi in China (Chen et al. 2012; Luo 2011), jeitinho in Brazil (Ardichvili et al. 2012), 'pulling strings' in English speaking countries (Smith et al. 2012) and blat in post-Soviet spaces (Ledeneva 2009, 2013). The aim of this article is to contribute to the advancement of knowledge in this area by evaluating critically the use of blat, not in post-Soviet spaces, but across transnational spaces, exploring how Eastern European migrant entrepreneurs living in the UK access, construct and maintain blat social networks using resources in both their home countries and in the UK. Extant literature presents blat networks as becoming monetarized with individuals increasingly using them to accrue economic capital within post-Soviet spaces (Smith and Stenning 2006). In this article, however, we explore the non-economic resources that remain salient in the journeys of migrant entrepreneurs. To address this gap, we address two core research questions: what mechanisms facilitate blat to function across transnational spaces? What conditions enable blat networks to function in transnational spaces?

To address these questions, we draw on Bourdieu's (1986) 'forms of capital' approach to explore how migrant entrepreneurs in the UK often leverage capital in divergent ways to set up and sustain businesses. While the extant literature shows how migrant entrepreneurs mobilize different forms of capital to further their business ventures (Baltar and Icart 2013; Plüss 2011; Vershinina et al. 2011), here we focus on the underexplored form of symbolic capital understood as the prestige, status and positive reputation individuals possess in the eyes of others (Terjesen and Elam 2009).

While the importance of social networks to migration experiences is well documented (Castles and Miller 2003; Faist and Ozveren 2004), in this article we respond to calls to look beyond the tendency to see migrants as having 'ready-made' social networks and instead critically consider the actual practice of migrant network formation (Ryan 2007; Ryan and Mulholland 2014; Ryan et al. 2008). Using data generated between 2012 and 2014 from a qualitative study of Eastern European migrants in the UK, we draw further attention to how migrants access, maintain and construct social networks in the host country (Ryan 2011), focusing on the flow of resources not only within social networks in the UK but also, crucially, across transnational spaces between the UK and Eastern Europe. Over the past decade, increasing numbers of 'new' migrants have arrived in the UK (Jones et al. 2014) because of the rise in refugees and asylum seekers from war-torn countries (Edwards et al. 2016), as well as migration from the new EU member states (Ciupijus 2011; Khattab and Fox 2016) and other European countries such as the former Soviet states of Ukraine, Russia, Belarus and Moldova. Despite the growth of 'new' migrant communities in the UK, forming part of the 'age of super-diversity' (Meissner and Vertovec 2015; Vertovec 2007, 2014), such groups have rarely figured in contemporary debates on self-employment and/or entrepreneurship, other than in a few notable studies (Barrett and Vershinina 2017; Edwards et al. 2016; Ram et al. 2008). 
Our findings show how Eastern European migrants working in the UK transform the blat social networks formulated within the cultural and political contours of Soviet society. They highlight not only the monetarization of such networks but also the continuing embedded and important nature of trust existing within these networks, which cut across transnational spaces. Moreover, they demonstrate how forms of social and cultural capital based on language use (Russian) and legacies of a shared Soviet past, are as important as the role of 'co-ethnics' in facilitating small business development. Moreover, we highlight the significance of the under-researched notion of the leverage of symbolic capital across transnational work environments.

We have structured the article as follows. In the first section, we introduce literature on migrant and transnational forms of entrepreneurship and on the role of migrant social networks focused on blat as a social practice. In the second section, we present the methodology used in this study. In the third section, we outline the findings of our empirical study and emphasize the under-researched role of 'symbolic' capital in driving entrepreneurial practices. We conclude by reflecting on the contributions and implications for theory and practice before identifying directions for further research.

\section{Migrant and transnational forms of entrepreneurship}

The literature on migrant entrepreneurship has focused on the individual characteristics of entrepreneurs in terms of their social class, culture, ethnicity (Barrett and Vershinina 2017; Chaganti and Greene 2002; Koning and Verver 2013) and on the various forms of capital they utilize to enable or constrain their entrepreneurial practice. Alternative explanations are based on more 'structuralist' readings of societal arrangements (Portes 1994), which involve migrant entrepreneurs relying on the social capital of their ethnic group (Drori et al. 2009) in the absence of any other relevant economic options.

One outcome of recognizing that both structure and agency are important has been the emergence of a mixed embeddedness approach (Kloosterman 2010; Kloosterman et al. 1999) to understanding migrant forms of entrepreneurship (Ram et al. 2008; Vershinina et al. 2011) that takes the embeddedness of migrant entrepreneurs within co-ethnic networks into account and seeks to contextualize them within broader social, political and economic spaces within the host country (Ram et al. 2008). This approach focuses on the many difficulties that migrant entrepreneurs face in the host country (such as access to finance and training) as necessarily part of the social and political context of the host country (Ram et al. 2008). As such, the mixed embeddedness approach stresses the need to focus not only on ethnic strategies but also on personal strategies within specific opportunity structures, markets and regulatory environments.

Scholars often see social capital as a resource to enable migrant entrepreneurs to access co-ethnic social networks to gain finance (Vershinina et al. 2011). However, Sepulveda et al. (2011) argue that many have overstated the importance of social capital as a way of facilitating migrant entrepreneurial business operations. Related to this point, Ram et al. (2008) and Jones et al. (2014) have emphasized how social capital can have negative as well as positive effects on migrant populations. In their study of Somalis in Leicester, Ram et al. (2008) found that the social capital that these Somalis 
utilized in their business operations was a two-way resource, on the one hand to provide critical forms of economic capital to assist in the start-up of business ventures in the UK, while at the same time providing substantial amounts of money to Somali family and friends back 'home'. An outcome of recognizing the continuing importance of the 'home country' in the lives of many migrant entrepreneurs has been a growing academic focus on migrants' transnational economic practices (McKenzie and Menjívar 2011; Walther 2012; Wilding 2006). It is to this literature that we now turn.

Studies on migrant and transnational entrepreneurship use a variety of different definitions to understand immigrant and ethnic forms of entrepreneurship (Brzozowski et al. 2017). For this article, it is important to clarify the distinction between country of origin, newly formed host country and the relationships between the two. First, ethnic entrepreneurs are active in their ethnic enclaves in their host societies and often rely on their co-ethnic customers (Koning and Verver 2013). Second, transnational entrepreneurs, defined as 'social actors who generate networks, ideas, information and practices for the purpose of seeking business opportunities or maintaining businesses within dual social fields' (Drori et al. 2009), benefit from being present simultaneously within dual business environments, the host and home societies. As Walther (2012) outlines, the transnational entrepreneur exploits his or her positionality within dual fields, exploiting the opportunities to which entrepreneurs active in only one location do not have access. As Vertovec (2001) states, 'the in-between position of many transnational migrants may be grasped as an advantageous strategy' (Vertovec 2001: 18). Lastly, as Brzozowski et al. (2017) point out, there is a further need to differentiate between transnational entrepreneurs who operate between home and host countries, and transnational diaspora entrepreneurs who operate across multiple locations and crucially involve second and third generation migrants (Elo 2016; Mayer et al. 2015; Riddle and Brinkerhoff 2011).

Here, we focus on first generation transnational migrant entrepreneurs who maintain links with their home countries across Eastern Europe, while operating businesses in the UK. The literature on links with the home country has focused on how transnational migrant entrepreneurs take advantage of access to knowledge, capital and technology (Chen and Tan 2009; Drori et al. 2009) and on how networking across transnational spaces can positively impact on firm outcomes (Kariv et al. 2009). Moreover, Brzozowski et al. (2014) highlight that many transnational migrant entrepreneurs maintain links with the home country, seeing it as a 'backup option' if their businesses in the new, host country fail to develop. Our empirical findings, by contrast, point to alternative explanations. We now outline the key literature on social networks, which enables us to frame such alternative understandings.

\section{Migrant social networks}

Defining social capital as 'a particular kind of resource available to an actor', which 'inheres in the social structure of relations between actors and among actors' (Coleman 1988: 98) for migrant communities (Evergeti and Zontini 2006), scholars have focused on the importance of family and friendship networks in assisting and maintaining 
migration processes (Heering et al. 2004; Kilkey and Merla 2014). Rather than blindly seeing bonding social networks 'largely as an unmitigated good' (Edwards 2004), scholarly work has recognized the importance of dynamism across space and time within migrants' social networks (Ryan 2007) and of how social capital can have positive and negative impacts on migration processes and experiences (Edwards 2004; Ryan 2011) in the host society. Kelly and Lusis (2006) draw attention to the potential dangers new migrants face if they interact solely with co-ethnics who lack contacts in the wider host society. Such closed social networks align with the existence of negative social capital and the emergence of ethnic enclaves detached from the wider host society (Crowley and Hickman 2008). Within a UK context, there has been concern that ethnic minority businesses, located within ethnic enclaves, remain concentrated in low-order sectors (Smallbone et al. 2010).

An appreciation of positive and negative types of social relationships, which may lead to different forms of resources being accessible within migrant social networks, is clearly relevant. Indeed, to acknowledge the dynamism within social networks is to demonstrate the importance of recognizing the social positioning of different actors in a specific social network. To this end, Granovetter's (1973) theory of strong and weak ties seeks to differentiate their relative importance in a social network, with the strong ones associated with friends and family members holding similar views and having access to resources. Weak ties, by contrast, are mainly effective when bridging social distances. Developing this theory, Ryan (2011) argues that there is a need to differentiate between 'horizontal' and 'vertical' weak ties. Although Granovetter did not focus on migrants seeking to develop businesses in a host country, the theory of 'strong' and 'weak' ties may nevertheless be useful when examining the challenges migrants face when seeking to access social networks in a host society. Brzozowski et al. (2017) offer a concise review of the importance of ties for transnational migrant entrepreneurs during the start-up phase and later stages of business activity. While some studies (Katila and Wahlbeck 2012; Patel and Terjesen 2011) underline the importance of strong family ties in the start-up process, others either dismiss their importance (Smans et al. 2014), or, like Mustafa and Chen (2010), argue that they are not only important during the start-up phase but also for the continued success of transnational migrant entrepreneurial business activities. However, in this article, we seek to go beyond accounts that rely on strong family-based ties to explain transnational migrant entrepreneurship, and to focus our attention on the under-researched role of weak ties. We now move on to examine the role of blat.

\section{The role of blat}

The use of personal connections to 'get things done' and often to bypass formal rules and regulations is prevalent across many societies. Existing research outlines the use of jeitinho in Brazil (Ardichvili et al. 2012), 'pulling strings' in English-speaking countries (Smith et al. 2012), and guanxi - the 'interpersonal linkages with the implication of a continued exchange of favours' (Michailova and Worm 2003: 510) - in China, which plays a key role in the everyday 'doing' of Chinese business organizations (Chen 
et al. 2012; Luo et al. 2011). In the Arab world, wasta, which 'involves social networks of interpersonal connections rooted in family and kinship ties and implicating the exercise of power, influence, and information sharing through social and politico-business networks' (Hutchings and Weir 2006: 143), plays a vital role in everyday transactions (Hutchings and Weir 2006). Despite the diversity and scope of informal practices across different countries, the main purpose of these forms of informal behaviour is similar, namely to circumvent formal rules and provide beneficiaries with selectively redistributed favours and services (Aliyev 2017; Smith et al. 2012).

In Soviet times, the term blat referred to the use of personal connections to circumvent and navigate the intricacies of getting by in the Soviet deficit economy (Ledeneva 2009, 2013). As Ledeneva (2009: 257) argued, blat networks 'loosened up the rigid constraints of the political regime' and gave Soviet citizens an alternative way of negotiating goods and services on an everyday level, often bypassing the bureaucratic incompetence of the decaying Soviet system of scarce resource allocation. As such, people viewed blat as a way of 'getting things done' and, importantly, without any obligation to compensate for the assistance provided. Correspondingly, by representing an accumulation of symbolic capital, the ability to assist friends through a strong blat network conferred prestige and social status (Williams et al. 2013).

Following the collapse of the Soviet system, some scholars argue that blat has remained a social practice involving friendly assistance (Polese 2008; Wanner 2005). Others, however, claim that blat networks have become increasingly commodified with individuals using them to accumulate economic capital in the newly formed marketbased societies (Smith and Stenning 2006), thereby assigning the term a more negative meaning. While there is a clear assumption in the existing literature that people have refashioned the use of blat networks away from traditional forms of non-monetarized friendly assistance to an increasingly commodity-based understanding of personal connections, so far nobody has placed this under empirical scrutiny. To address this issue, in this article we examine how blat networks, involving non-economic as well as economic exchanges, function across transnational spaces and, and in so doing, emphasize the underexplored notion of symbolic capital. Before presenting the findings of our research study, we outline its key methodological issues.

\section{Methodological approach}

As Mallett and Wapshott (2015) identify, despite the current policy focus on harnessing entrepreneurship as a primary means of fostering economic development and growth, there is a lack of in-depth empirical work on the day-to-day aspects of entrepreneurial activity, especially in relation to transnational migrant entrepreneurs. In response, we examine the everyday practices of Eastern European entrepreneurs operating in three UK cities. Between 2011 and 2014, we conducted 31 in-depth qualitative interviews with entrepreneurs of different nationalities (see details in Table 1) lasting between 60 and 90 minutes (totalling 2,308 minutes). It is important to note that all the respondents were residing and working in the UK legally. Those from Latvia and Lithuania were EU citizens so could utilize their rights to live and work in the UK. Those from non- 
EU member states (Russians, Ukrainians, Belarusians and Moldovans) had visas that allowed them to live and work in the UK. All arrived in the country between 2007 and 2012. The interviews formed part of a wider research project on transnational migrant entrepreneurs in the UK. The participants were aged between 25 and 55 years; 18 of them were men and 13 were women.

We used a variety of means to develop our sample of Eastern European entrepreneurs, including contacting migrant groups and community organizations, and following up on personal links in Eastern Europe and the UK. This 'chain referral sampling' (Penrod et al. 2003) is useful in that it eliminates the risk of over-relying on a narrow set of social contacts and other studies have recently used it to study new migrant communities in the UK (Jones et al. 2014; Vershinina and Rodionova 2011). We present detailed demographic data about our respondents in Table 1.

Table 1: Profile of participants

\begin{tabular}{|c|c|c|c|}
\hline Case No. & Name, Gender and Age & Nationality & Business \\
\hline 1 & Natalya, (F), 47 & Ukraine & Cleaning Business \\
\hline 2 & Nadya, (F), 33 & Moldova & Online clothes shop \\
\hline 3 & Yura, (M), 32 & Latvia & Plumber \\
\hline 4 & Slava, (M), 27 & Ukraine & Taxi Driver \\
\hline 5 & Katya, (F), 33 & Russia & Nail technician \\
\hline 6 & Ira, $(\mathrm{F}), 40$ & Belarus & Hairdressing \\
\hline 7 & Evgen, (M), 26 & Latvia & Courier \\
\hline 8 & Oleksiy, (M), 44 & Ukraine & Car Mechanic \\
\hline 9 & Vitaly, (M), 52 & Ukraine & Migrant Advice \\
\hline 10 & Anatoliy, (M), 43 & Moldova & Joiner \\
\hline 11 & Luda, (F), 38 & Ukraine & Grocery Store \\
\hline 12 & Svetlana, (F), 36 & Russia & Therapist \\
\hline 13 & Mikhail, (M), 30 & Latvia & Taxi Driver \\
\hline 14 & Lukas, (M), 32 & Lithuania & Electrician \\
\hline 15 & Mariya, (F), 31 & Ukraine & Property \\
\hline 16 & Gleb, (M), 48 & Russia & Home Repairs \\
\hline 17 & Lena, $(\mathrm{F}), 34$ & Ukraine & Nail technician \\
\hline 18 & Anatoliy, (M), 33 & Ukraine & Car Business \\
\hline 19 & Sasha, (M), 28 & Lithuania & Plumber \\
\hline 20 & Vlad, (M), 31 & Russia & Documents \\
\hline 21 & Ivan, (M), 38 & Russia & Computer Software \\
\hline 22 & Vika, (F), 42 & Ukraine & Property \\
\hline 23 & Dima, (M), 44 & Moldova & Electrician \\
\hline 24 & Yura, (M), 32 & Ukraine & Courier \\
\hline 25 & Nastya, (F), 29 & Moldova & Hairdressing \\
\hline 26 & Katyr, (F), 27 & Latvia & Car Wash Business \\
\hline 27 & Nikolay, (M), 29 & Moldova & Clothes Business \\
\hline 28 & Maksim, (M), 38 & Ukraine & Car mechanic \\
\hline 29 & Vika, (F), 32 & Russia & Interior Designer \\
\hline 30 & Nadya, (F), 35 & Belarus & Cleaning Business \\
\hline 31 & Dima, (M), 41 & Ukraine & Restaurant \\
\hline
\end{tabular}


The interviews were semi-structured and recorded with each respondent's consent and transcribed verbatim. We undertook thematic analysis, coding the data to explore emergent themes. Our lead researcher who is a native English-speaker but fluent in the Russian and Ukrainian languages conducted the interviews in a combination of English, Russian and Ukrainian. Our second author, who also speaks these three languages, checked the transcripts for accuracy. We employed a constant comparative approach to data analysis (Silverman 2005), with descriptive themes iteratively emerging from the data. We considered the themes in relation to the existing literature, so allowing the researchers to reflect constantly on the links between the data and the literature, which is an approach that scholars have previously used (McKeever et al. 2014). Although Jack and Anderson (2002) assert that in-depth qualitative research can lack generalizability, in the context of this study it is appropriate to identify new insights about the practice of entrepreneurial migrants engaging in transnational entrepreneurship.

\section{Findings}

We set out to examine what mechanisms allow blat networks to function in transnational spaces. We focused on migrant entrepreneurs who had set up businesses in the UK and explored our participants' entrepreneurial practices with a view to discovering how they leverage and accrue their capital resources. The stories and everyday experiences of entrepreneurship unfolded in a variety of ways during the research process. A core narrative to emerge from our data concerned social capital leveraged through family ties. This highlighted how social capital can facilitate migrant journeys to entrepreneurship. Disappointed with labour market opportunities in Latvia, Yura (INT: 3) decided to take up the offer of some assistance in setting up a business in the UK. As he put it, 'my friend and I have been working as plumbers here for a couple of years now. We started working cash-in-hand and set up [a] business with [the] help of some relatives of my mother. People got to know us slowly.' Prior to the help from his mother's friends (social capital), Yura had plumbing experience and a desire to develop a business in the UK, but did not know how to begin. The use and enactment of the social capital gave him the trigger to kick-start his UK business. Such examples echo the findings of Light and Gold (2000) who argue that migrant families' transnational social ties can play a vital role in shaping ethnic economic arrangements.

However, while several interviewees had social capital embodied in family ties, they could also enact it from being members of wider social networks beyond family or ethnic ties. Ira (INT: 6), a Belarusian national, mentioned how her entrepreneurial practices had developed over time after working in the UK as a hotel cleaner in a formal work environment:

We all work as cleaners in a hotel. We wanted to earn more money and with some of the other girls, we set up a small hair-styling business. We put adverts on the internet and in shop windows. The response has been good. There's a large Russian-speaking community here and Russians, Ukrainians and Kazakhs are now our clients. 
In this case, we see how Ira's interaction with work colleagues in the formal work sphere generated social capital. She saw an opportunity to mobilize an entrepreneurial practice, which was now complementing her formal work employment (Williams 2011) and providing a business to develop through access to migrant networks, not tied together solely by ethnicity (Crowley and Hickman 2008; Koning and Verver 2013; Ram et al. 2016), but through shared Russian language use and associated cultural values (Vershinina et al. 2011). Similarly, Antoliy (INT: 10), a joiner, highlighted how being a member of the Russian-speaking community in his city had provided him with more business opportunities than solely engaging with fellow Moldovans (I have several guys from Russia, Ukraine and Latvia working with me. It is not important that they are not Moldovan. What is important is that they are nashi - 'one of us'.)

While highlighting the importance of social capital as a catalyst for entrepreneurial practice, such examples demonstrate that migrants accrue forms of capital in the UK, the 'host country', not only through family ties (Light and Gold 2000) or from within 'co-ethnic' networks (Ram et al. 2008), but also through being nashi - a member of a wider Russian-speaking community with a shared Soviet past. This replicates the findings of a study on Polish migrants operating in Leicester in the English Midlands (Vershinina et al. 2011). Beyond these examples, what became evident is that everyday interactions with people of different nationalities but of similar standing in the society (namely being a migrant in the UK and sharing a language) enabled these individuals to draw on and command resources in 'co-migrant' networks that went beyond the simple contours of ethnicity, and to transfer them into transnational spaces.

\section{Vertical and horizontal weak ties}

A further prominent narrative emerged over how migrants access and utilize the social networks and types of ties at their disposal (Bourdieu 1986; Ryan et al. 2008). Slava (INT: 4), a Ukrainian national, came to the UK several years ago. However, following the loss of his job as a hotel porter, he saw the potential use of his vehicle as a capital resource and started his unofficial taxi service. As he explained, 'in Ukraine lots of people work as taxi drivers. When I lost my job, I decided to use my mini-van as a taxi and courier service. I have lots of work now in the city ... our people like to use me, and they help me in other ways too.' Slava explained how while living in the Ukraine, he had enlisted the help of his brother, who had lived in Britain for several years, to get the necessary (forged) documents to enter the UK, thus highlighting how social capital enabled through active family networks (Vershinina et al. 2011) can facilitate entrepreneurial practices. Slava also described how his poor English and illegal status had forced him into engaging in informal entrepreneurial activities while in the UK. Moreover, being a member of the Ukrainian community was 'like a double-edged sword', he said, and while 'our people are ready to help', this help often came with binding terms and conditions attached. Although now earning a decent wage, Slava bemoans the fact that 'my English is not improving' and 'I cannot gain any new clients; I feel stuck here now', thus highlighting how he felt constrained within the Ukrainian community in the city. Slava's example points to the dangers of migrants maintaining 
solely 'horizontal' ties, which necessarily reinforce their marginalization within the host society (Ram et al. 2016). As Granovetter (1983: 213) noted, 'this pervasive use of strong ties by the poor and insecure is a response to economic pressures; they believe themselves to be without alternatives. ... Individuals so encapsulated may then lose some of the advantages associated with the outreach of weak ties.'

By contrast, however, several interviewees expressed a desire to embed their business activities more widely in the UK. As well as leveraging social capital from within family or network ties (co-migrant or otherwise), they strove to learn how to get by and be successful in the UK. As Lukas (INT: 14) explained:

I arrived from Vilnius five years ago and set up my electrician business. At first, I survived through word of mouth in the city. Soon, I realized that I needed to make the next step. I enrolled on a training course. It has been great. I've got a qualification from it, met some really useful people, and all the while my English has been getting better.

Lukas drew attention to how his contacts in the Lithuanian community 'had been only useful for a while', thus emphasizing the temporal nature of co-ethnic support networks. He realized that to develop his business beyond the constraints of his ethnic enclave, it was important to stay in touch with several of the other individuals on the training course who 'helped me understand how business works here in the UK'. Similarly, Katya (INT: 5) and Lena (INT: 17) explained that, with the passing of time, they shifted the focus from relying on co-ethnic customers to widening the scope of their businesses. Both these respondents sought external advice (in Katya's case from a local women's enterprise association and in Lena's from an English colleague at her son's play group), thus demonstrating the importance of weak ties in driving entrepreneurial pursuits.

Such examples of acquiring contacts in the indigenous population, outside immediate strong-tie networks, show how vertical weak ties (Granovetter 1973) can generate access to relevant and useful information to aid business development. Lena explained how speaking English on a more regular basis at external events meant that over time 'her confidence improved, and she felt able to not just talk about her homeland but actually discuss business ideas and opportunities'. Svetlana (INT: 12), who had worked as a therapist in Russia for many years, described her initial disappointment over the UK not recognizing her qualifications. However, she explained that through the financial support of her British husband, she managed to enrol on a training course where she not only managed to get the necessary qualifications to start her therapy business but also met many people who became her friends and 'pointed her in the right directions' in terms of the market for therapists in the UK.

Beyond these examples, the importance of weak ties became apparent during our respondents' journeys. Moreover, their ability to maintain access to the resources of both the ethnic and mainstream economy helped them to develop their businesses. Several of the respondents stressed how ties based exclusively in co-ethnic migrant networks lose their potency over time and newly accrued forms of capital replace them. 


\section{Accumulation of transnationally embedded symbolic capital}

Another central narrative relates to the transnational nature of the social networks into which Eastern European migrant entrepreneurs tap and which accrued forms of symbolic capital underpin. It is evident from our respondents' accounts that the growth of globalization, as well as the advent of the internet and Skype, have enabled these migrants to maintain transnational ties through regular and affordable communication (Baldassar et al. 2016; Perkins and Neumeyer 2013).

Several participants spoke about their 'positionality' of living and owning a business in the UK giving them respect and a new authority (avtoritet) 'among my friends back home'. Anatoliy (INT: 18) had arrived in the UK from Ukraine more than ten years ago and had gradually developed a small car exporting business.

People in Ukraine look at me differently now. Now they see a successful businessman, not in Ukraine where everything depends on who you know, but in the UK, an advanced country. It's helped my car business in the UK. Customers see they'll get a quality product and I've built a good reputation.

Like Anatoliy, Nikolay (INT: 27) explained, when he opened a chain of clothing shops in Moldova several years earlier, he found that being known as a someone with 'UK operations' meant that people 'looked up to him' and considered him a 'serious businessman'. Nikolay said that this gave him access to 'the right people' in Kishinev's business circles to help him expand his chain of clothing shops across Moldova, thus enabling him subsequently to invest further in his UK business.

While such examples highlight how migrants can gain 'respect' in their home countries, other interviewees demonstrated how they accrued similar forms of symbolic capital in the UK. For example, that Vitaly (INT: 9) has businesses in the UK, Germany and Austria clearly demonstrates the importance of transnational connections (Vertovec 2007). He constantly uses Skype and WhatsApp to keep his businesses across different national jurisdictions ticking over. In the UK, he started by setting up an informal online migrant advice consultancy for the country's Russian speaking population. With his knowledge of the Russian language and his breadth of business experience from Germany and Austria, his business generates a steady income, which he uses to maintain his existence in the UK and to support his other businesses in Germany and Austria. As he puts it, "people know who I am and what I can do for them', which clearly gives Vitaly some prestige and respect within the Russian-speaking community in the UK. These examples indicate how the accrual of symbolic capital translates across transnational spaces and enables individuals to earn respect, as well as claim credibility and legitimacy, in both their country of origin and in the co-ethnic, co-migrant and wider host country communities. It is important to note that the relevance of avtoritet was only specific to the narratives of the non-EU respondents in our study. These individuals have, in the eyes of family, friends and others in their home countries, leveraged forms of accrued symbolic capital to facilitate their business operations in both the UK and back home. By contrast, the 
need to accrue symbolic capital is much lower for the EU citizens in our study because of their ability to live and work anywhere in the EU. As Katyr (INT: 26) states, 'anyone can get on a bus and come to England.' Hence, our findings tentatively point out that, despite clear commonalities, transnational migrant entrepreneurs can use blat in diverse ways.

\section{Refashioning blat networks}

Underpinning social capital and its transnational nature is the ability of transnational migrant entrepreneurs to harness the blat networks that they own and in which they participate. They also employ weak ties to develop businesses beyond the ethnic enclave and use transnationally embedded symbolic capital to create confidence. In this study, it became apparent that individuals in possession of transnational social capital who have links with key individuals in co-ethnic, co-migrant and wider communities engage in the accumulation and exchange of symbolic capital in the form of 'respect', 'credibility', 'legitimacy' and 'authority'. In doing so, they extend the reach of their transnational social networks and thus generate economic capital. Previous literature essentializes social capital as the primary engine for the creation of economic capital by migrant entrepreneurs. In our study, we see the significance of symbolic capital in fuelling entrepreneurial activities.

Vlad (INT: 20), the partner of a UK citizen, used Russian language web forums to arrange documents for people wishing to work and live legally in the UK. As he put it, 'I earn money through my contacts to sort out documents. There are lots of Russians/ Ukrainians who need the correct documents to look legal. We have lots of 'legals' now from the Baltics - their documents become transferrable ... for a price of course.' He went on to explain how he had gained 'respect' in the Russian-speaking community for 'getting people's documents sorted quickly and efficiently'. Over the years, he built up a reputation among non-EU citizens from countries such as Moldova, Ukraine and Russia who had invariably overstayed their visas and needed his help to sort out their documents. Vlad's ability to access symbolic capital to his financial advantage meant, in his own words, 'making the most of my contacts' and 'using my access to people'. He clearly saw his informal contacts as a way of improving his financial position; in other words, he sought to monetarize and commodify his existing blat networks (Ledeneva 2009, 2013).

Nadya (INT: 30), who has her own cleaning business in the UK, explains the importance of her 'circle of friends' from back home in Minsk in Belarus. She explains how since leaving university more than ten years ago, the group has remained in close contact and they 'look after each other'. Nadya highlights how she is 'proud' that she was able to help a friend set up a business in the UK last year and feels that she has gained some 'prestige' and respect in the local community. Because of this, she says, 'people know who I am now and how I look after my family and friends back home and [that I] have the resources and desire to aid my friend here also.' Faist and Ozveren (2004) differentiate between kinship networks, which often involve deeply embedded links, and the looser, more diffuse, informal ones. Yet, Nadya's experience shows that 
impersonal ties not based on kinship but maintained within transnational contexts also have a strong capacity to effect entrepreneurial practices.

Ivan (INT: 21), originally from Moscow, spoke of the importance of having not only relevant contacts but also 'respect' in a given community. He moved to the UK more than six years ago and worked as a computer specialist, but also set up a car-wash business and began to employ 'our people'. He mentioned how his reputation had grown in the city - 'people know who I am and know that I am an honest businessman,' so they 'constantly come back and recommend my services'. Such embedded networks involving one's own people (svoi lyudi), point to the continued importance attached to notions of trust, loyalty and obligation within blat networks across transnational spaces, which is a finding that contradicts much of the existing literature.

Vitaly (INT: 9), by contrast, whom we discussed earlier, is a 'fixer' or 'blat expert' (what the Soviets call a tolkach) - the person whom Soviet enterprises would hire to navigate the maze of Soviet bureaucracies and get things done relatively efficiently. In the Soviet and post-Soviet periods, Vitaly had worked as a procurement manager for a large firm in eastern Ukraine, which involved him 'knowing lots of useful people' and 'getting things done' without the fuss of having to follow all the bureaucratic procedures. Today, he stresses the importance of having trusted individuals (svoikh ludyei) working in each of his businesses across different countries. His network of contacts includes friends 'who worked and studied together back in the Soviet days in Ukraine'. Vitaly mentioned how 'we all aim to help each other out when someone asks for help' and made it clear that there was no expectation of reciprocity. Such comments demonstrate the continuing importance of blat as a social practice that stresses friendly assistance (Polese 2008; Wanner 2005), trust and working to bind and reinforce a social network of individuals. While blat relations emerged in the late Soviet period to navigate the intricacies of a failing Soviet economy, today people use them to develop their entrepreneurial pursuits across transnational borders that lie beyond the contours of post-Soviet spaces.

\section{Conclusion}

In this article, we set out to explore what made Eastern European transnational migrant entrepreneurs use blat networks across transnational spaces and, to this end, conducted 31 semi-structured interviews with entrepreneurs in the UK. We shed a critical eye on the tendency to see migrants as having 'ready-made' social networks (Ryan 2007; 2011) and, instead, considered how migrant networks form in practice. While studies recognize the possibility of transferring and transforming different forms of capital, there was always an underlying assumption that the nation-state was the clear unit of investigation without examining the possibility of leveraging and mobilizing forms of capital across transnational spaces, or recognizing the multifaceted nature of migrant experiences. While much of the research on migrant social networks has focused on the importance of family, 'co-ethnic' and 'co-migrant' links, our findings show that networks based on shared Russian language use and legacies of a shared Soviet past are just as (or even more) important in driving entrepreneurial pursuits as the role of 
'co-ethnics'. While much of the literature on transnational migrant entrepreneurship has focused on the importance of strong familial ties (Katila and Wahlbeck 2012; Mustafa and Chen 2010; Patel and Terjesen 2011), in this article we explain the impact of weak ties on transnational migrant entrepreneurship. Our findings reveal the importance of differentiating between forms of 'weak ties', which are not all equal in value. While horizontal ties can aid small business development, several interviewees emphasized the need to look beyond immediate, co-ethnic networks and instead recognize the importance of developing 'vertical' connections and activating one's social capital to gain access to resources and forms of capital across the wider host society. This suggests potential avenues for future research. It would be fruitful to examine the dynamic nature of ties to establish whether they continue to accumulate or erode over time (Brzozowski et al. 2017); the current literature fails to provide a coherent view of the relationship between types of ties and the sustainability of their intensity in the context of transnational migrant entrepreneurship. Further studies could examine the potential role of sectors in understanding how ties influence transnational migrant entrepreneurship. While here we found no striking differences between the sectors in which our respondents engaged, future work could explore whether there are differences in the use of networks between low-skilled services and complex business operations.

Our findings stress the significance of leveraging the under-researched notion of 'symbolic capital' across transnational spaces. We demonstrate that the status and prestige of being a 'successful businessperson in the UK', with access to cheap finance, had a positive impact on some entrepreneurial pursuits. Intriguingly, individuals from countries in the former Soviet Union, such as Ukraine and Moldova, can access 'symbolic capital' through the status bestowed in those countries on those who have managed to migrate to the UK. Some accrue symbolic capital from within the co-ethnic community, some acquire it through their co-migrant experiences (shared language and historical values), while for others it comes from the wider community in the UK host society.

Moreover, our findings demonstrate how the everyday lived experiences of Eastern European migrants working in the UK can transform blat social networks previously formulated within the cultural and political contours of Soviet society. Our findings highlight not only how blat networks become monetarized but also how they continue to promote the access of trusted individuals to sources of power and capital and how such processes operate across transnational spaces. Far from seeing the ability to maintain blat networks in a negative light (Ledeneva 2013), we found that our respondents viewed them in a wholly positive light, which not only improved their access to various forms of capital but also enabled them to accumulate symbolic capital, which further advanced their business operations.

To summarize, in this article we make the following contributions to the literature. First, we draw attention to the shift among Eastern European transnational migrant entrepreneurs towards relying on co-migrant rather than co-ethnic networks, and to the temporal nature of co-ethnic social capital in business development. Second, we explain the importance of horizontal weak ties (shared ethnicity and language) in establishing business operations for transnational migrant entrepreneurs and, correspondingly, the function of vertical weak ties across wider streams of the host society and 
transnationally in enabling subsequent business growth. Third, we provide a more nuanced understanding of the role that symbolic capital plays in transnational migrant entrepreneurial journeys and its multifaceted nature. Finally, we point to the continued emphasis placed on trust and loyalty, despite the depiction in the literature of blat networks becoming increasingly monetarized. Moreover, for the first time, we demonstrate the relevance of blat networks functioning across transnational spaces.

\section{References}

Aliyev, H. (2017) 'Informal institutions in Azerbaijan: exploring the intricacies of tapsh', Europe-Asia Studies, 69 (4), 594-613, doi: 10.1080/09668136.2017.1329404.

Ardichvili, A., D. Jondle, B. Kowske, E. Cornachione, J. Li and T. Thakadipuram (2012) 'Ethical cultures in large business organizations in Brazil, Russia, India and China', Journal of Business Ethics, 105 (4), 415-28, doi: 10.1007/s10551-011-0976-9.

Baldassar, L., M. Nedelcu, L. Merla and R. Wilding (2016) 'ICT-based co-presence in transnational families and communities: challenging the premise of face-to-face proximity in sustaining relationships', Global Networks, 16 (2), 133-44, doi: 10.1111/glob.12108.

Baltar, F. and I. B. Icart (2013) 'Entrepreneurial gain, cultural similarity and transnational entrepreneurship', Global Networks, 13 (2), 200-20, doi: 10.1111/glob.12020.

Barrett, R. and N. Vershinina (2017) 'Intersectionality of ethnic and entrepreneurial identities: a study of post-war Polish entrepreneurs in an English city', Journal of Small Business Management, 55 (3), 430-43, doi: 10.1111/jsbm.12246.

Bourdieu, P. (1986) 'The forms of capital', in J. Richardson (ed.) Handbook of theory and research for the sociology of education, New York: Greenwood Press, 241-58.

Brzozowski, J., M. Cucculelli and A. Surdej (2014) 'Transnational ties and performance of immigrant entrepreneurs: the role of home-country conditions', Entrepreneurship and Regional Development, 26 (7/8), 546-73, doi: 10.1080/08985626.2014.959068.

Brzozowski, J., M. Cucculelli and A. Surdej (2017) 'The determinants of transnational entrepreneurship and transnational ties' dynamics among immigrant entrepreneurs in ICT sector in Italy', International Migration, 55 (3), 105-25, doi: 10.1111/imig.12335.

Castles, S. and M. Miller (2003) The age of migration: international population movements in the modern world, Basingstoke: Palgrave.

Chaganti, R. and P. G. Greene (2002) 'Who are ethnic entrepreneurs? A study of entrepreneurs' ethnic involvement and business characteristics', Journal of Small Business Management, 40 (2), 126-43, doi: 10.1111/1540-627X.00045.

Chen, W. and J. Tan (2009) 'Understanding transnational entrepreneurship through a network lens: theoretical and methodological considerations', Entrepreneurship Theory and Practice, 33 (5), 1079-91, doi: 10.1111/j.1540-6520.2009.00335.x.

Chen, C. C., X.-P. Chen and S. Huang (2012) 'Chinese guanxi: an integrative review and new directions for future research', Management and Organization Review, 9 (1), 167-207, doi: 10.1111/more.12010.

Ciupijus, Z. (2011) 'Mobile central eastern Europeans in Britain: successful European Union citizens and disadvantaged labour migrants?', Work, Employment and Society, 25 (3), 540-50, doi: 10.1177/0950017011407962.

Coleman, J. (1988) 'Social capital in the creation of human capital', American Journal of Sociology, 94, S95-S120, doi: 10.1086/228943.

Crowley, H. and M. Hickman (2008) 'Migration, post-industrialism and the globalised nation', Ethnic and Racial Studies, 31 (7), 1222-44, doi: 10.1080/01419870701725904.

Drori, I., B. Honig and M. Wright (2009) 'Transnational entrepreneurship: an emergent field of study', Entrepreneurship Theory and Practice, 33 (5), 1001-22, doi: 10.1111/j.15406520.2009.00332.x. 
Edwards, R. (2004) 'Present and absent in troubling ways: families and social capital debates', Sociological Review, 52 (1), 1-21, doi: 10.1111/j.1467-954X.2004.00439.x.

Edwards, P., M. Ram, T. Jones and S. Doldor (2016) 'New migrant businesses and their workers: developing, but not transforming, the ethnic economy', Ethnic and Racial Studies, 39 (9), 1587-617, doi: 10.1080/01419870.2015.1116702.

Elo, M. (2016) 'Typology of diaspora entrepreneurship: case studies in Uzbekistan', Journal of International Entrepreneurship, 14 (1), 121-55, doi: 10.1007/s10843-016-0177-9.

Evergeti, V. and E. Zontini (2006) 'Some critical reflections on social capital, migration and transnational families', Ethnic and Racial Studies, 29 (6), 1025-39, doi: 10.1080/014198706 00960271.

Faist, T. and E. Ozveren (2004) (eds), Transnational social spaces: agents, networks and institutions, Aldershot: Ashgate.

Granovetter, M. (1973) 'The strength of weak ties', American Journal of Sociology, 78 (6), 1360-80, doi: $10.1086 / 225469$.

Granovetter, M. (1983) 'The strength of weak ties: a network theory revisited', Sociological Theory, 1, 201-33, doi: 10.2307/202051.

Heering, L., R. van der Erf and L. van Wissen (2004) 'The role of family networks and migration culture in Moroccan emigration', Journal of Ethnic and Migration Studies, 30 (2), 323-37, doi: 10.1080/1369183042000200722.

Hutchings, K. and D. Weir (2006) 'Guanxi and wasta: a comparison', Thunderbird International Business Review, 48 (1), 141-58, doi: 10.1002/tie.20090.

Jack, S. L. and A. R. Anderson (2002) 'The effects of embeddedness on the entrepreneurial process', Journal of business Venturing, 17 (5), 467-87, doi: 10.1016/S0883-9026(01)00076-3.

Jones, T., M. Ram, A. Kiselinchev and L. Muchenje (2014) 'Mixed embeddedness and new migrant enterprise in the UK', Entrepreneurship and Regional Development, 26 (5/6), 500-20, doi: 10.1080/08985626.2014.950697.

Kariv, D., T. V. Menzies, G. A. Brenner and L. J. Filion (2009) 'Transnational networking and business performance: ethnic entrepreneurs in Canada', Entrepreneurship and Regional Development, 21 (3), 239-64, doi: 10.1080/08985620802261641.

Katila, S. and Ö. Wahlbeck (2012) 'The role of (transnational) social capital in the start-up processes of immigrant businesses: the case of Chinese and Turkish restaurant businesses in Finland', International Small Business Journal, 30 (3), 294-309, doi: 10.1177/02662426103 83789.

Kelly, P. and T. Lusis (2006) 'Migration and the transnational habitus: evidence from Canada and the Philippines', Environment and Planning A, 38 (5), 831-47, doi: 10.1068/a37214.

Khattab, N. and J. Fox (2016) 'East-European immigrants responding to the recession in Britain: is there a trade-off between unemployment and over-qualification?', Journal of Ethnic and Migration Studies, 42 (11), 1774-89, doi: 10.1080/1369183X.2016.1166040.

Kilkey M. and L. Merla (2014) 'Situating transnational families' care-giving arrangements: the role of institutional contexts', Global Networks, 14 (2), 210-29, doi: 10.1111/glob.12034.

Kloosterman, R. (2010) 'Matching opportunities with resources', Entrepreneurship and Regional Development, 22 (1), 25-45, doi: 10.1080/08985620903220488.

Kloosterman, R., J. van der Leun and J. Rath (1999) 'Mixed embeddedness: (in)formal activities and immigrant businesses in the Netherlands', International Journal of Urban and Regional Research, 23 (2), 252-66, doi: 10.1111/1468-2427.00194.

Koning, J. and M. Verver (2013) 'Historicizing the "ethnic" in ethnic entrepreneurship: the case of the ethnic Chinese in Bangkok', Entrepreneurship and Regional Development, 25 (5/6), 325-48, doi: 10.1080/08985626.2012.729090.

Ledeneva, A. V. (2009) 'From Russia with blat: can informal networks help modernize Russia?', Social Research, 76 (1), 257-88, available at: https://muse.jhu.edu/article/527659/pdf.

Ledeneva, A.V. (2013) Can Russia modernise? Sistema, power networks and informal governance, Cambridge: Cambridge University Press. 
Light I. and S. Gold (2000) Ethnic economies, San Diego: Academic Press.

Luo, J.-D. (2011) 'Guanxi revisited: an exploratory study of familiar ties in a Chinese workplace', Management and Organization Review, 7 (2), 329-51, doi: 10.1111/j.1740-8784.2011.00230.x.

Luo, Y., Y. Huang and S. Lu Wang (2011) 'Guanxi and organisational performance: a metaanalysis', Management and Organization Review, 8 (1), 139-72, doi: 10.1111/j.17408784.2011.00273.x.

McKeever, E., A. Anderson and S. Jack (2014) 'Entrepreneurship and mutuality: social capital in processes and practices', Entrepreneurship and Regional Development, 26 (5/6), 453-77, doi: $10.1080 / 08985626.2014 .939536$.

McKenzie, S. and C. Menjívar (2011) 'The meanings of migration, remittances and gifts', Global Networks, 11 (1), 63-81, doi: 10.1111/j.1471-0374.2011.00307.x.

Mallett, O. and R. Wapshott (2015) 'Making sense of self-employment in late career understanding the identity work of olderpreneurs', Work, Employment and Society, 29 (2), 250-66, doi: 10.1177/0950017014546666.

Mayer, S. D., A. Harima and J. Freiling (2015) 'Network benefits for Ghanaian diaspora and returnee entrepreneurs', Entrepreneurial Business and Economics Review, 3 (3), 95-122, doi: 10.15678/EBER.2015.030306.

Meissner, F. and S. Vertovec (2015) 'Comparing super-diversity', Ethnic and Racial Studies, 38 (4), 541-55, doi: 10.1080/01419870.2015.980295.

Michailova, S. and V. Worm (2003) 'Personal networking in Russia and China: blat and guanxi', European Management Journal, 21 (4), 509-19, doi: 10.1016/S0263-2373(03)00077-X.

Mustafa, M. and S. Chen (2010) 'The strength of family networks in transnational immigrant entrepreneurship', Thunderbird International Business Review, 52 (2), 97-106, doi: 10.1002/tie.20317.

Patel, P. C. and S. Terjesen (2011) 'Complementary effects of network range and tie strength in enhancing transnational venture performance', Strategic Entrepreneurship Journal, 5 (1), 58-80, doi: 10.1002/sej.107.

Penrod, J., D. Preston, R. Cain and M. Starks (2003) 'A discussion of chain referral as a method of sampling hard-to-reach populations', Journal of Transcultural Nursing, 14 (2), 100-7, doi: $10.1177 / 1043659602250614$.

Perkins, R. and E. Neumayer (2013) 'The ties that bind: the role of migrants in the uneven geography of international telephone traffic', Global Networks, 13 (1), 79-100, doi: 10.1111/j.1471-0374.2012.00366.x.

Plüss, C. (2011) 'Baghdadi Jews in Hong Kong: converting cultural, social and economic capital among three transregional networks', Global Networks, 11 (1), 82-96, doi: 10.1111/j.14710374.2011.00308.x.

Polese, A. (2008) "If I receive it, it is a gift; if I demand it, then it is a bribe": on the local meaning of economic transactions in post-Soviet Ukraine', Anthropology in Action, 15 (3), 47-60, doi: 10.3167/aia.2008.150305.

Portes, A. (1994) 'The informal economy and its paradoxes', in N. J. Smelser and R. Swedberg (eds) The handbook of economic sociology, Princeton: Princeton University Press, 119-34.

Ram, M., N. Theodorakopoulos and T. Jones (2008) 'Forms of capital, mixed embeddedness and Somali enterprise', Work, Employment and Society, 22 (3), 427-46, doi: 10.1177/ 0950017008093479.

Ram, M., T. Jones and M. Villares-Varela (2016) 'Migrant entrepreneurship: reflections on research and practice', International Small Business Journal, 35 (1), 3-18, doi: 10.1177/ 0266242616678051 .

Riddle, L. and J. Brinkerhoff (2011) 'Diaspora entrepreneurs as institutional change agents: the case of Thamel.com', International Business Review, 20 (6), 670-80, doi: 10.1016/ j.ibusrev.2011.02.013.

Ryan, L. (2007) 'Migrant women, social networks and motherhood: the experiences of Irish nurses in Britain', Sociology, 41 (2), 295-312, doi: 10.1177/0038038507074975. 
Ryan, L. (2011) 'Migrants' social networks and weak ties: accessing resources and constructing relationships post-migration', Sociological Review, 59 (4), 707-24, doi: 10.1111/j.1467-954 X.2011.02030.x.

Ryan, L. and J. Mulholland (2014) 'French connections: the networking strategies of French highly skilled migrants in London', Global Networks, 14 (2), 148-66, doi: 10.1111/ glob.12038.

Ryan, L., R. Sales, M. Tilki and B. Siara (2008) 'Social networks, social support and social capital: Polish migrants in London', Sociology, 42 (4), 672-90, doi: 10.1177/003803850809 1622 .

Sepulveda, L., S. Syrett and F. Lyon (2011) 'Population super-diversity and new migrant enterprise: the case of London', Entrepreneurship and Regional Development, 23 (7/8), 469-97, doi: 10.1080/08985620903420211.

Silverman, D. (2005) Doing qualitative research: a practical handbook, London: Sage.

Smallbone, D., J. Kitching and R. Athayde (2010) 'Ethnic diversity, entrepreneurship and competitiveness in a global city', International Small Business Journal, 28 (2), 174-90, doi: $10.1177 / 0266242609355856$.

Smans, M., S. Freeman and J. Thomas (2014) 'Immigrant entrepreneurs: the identification of foreign market opportunities', International Migration, 52 (4), 144-56, doi: 10.1111/ imig.12124.

Smith, A. and A. Stenning (2006) 'Beyond household economies: articulations and spaces of economic practice in postsocialism', Progress in Human Geography, 30 (2), 190-213, doi: 10.1191/0309132506ph601oa.

Smith, P., H. J. Huang, C. Harb and C. Torres (2012) 'How distinctive are indigenous ways of achieving influence? A comparative study of guanxi, wasta, jeitinho, and "pulling strings", Journal of Cross-Cultural Psychology, 43 (1), 135-50.

Terjesen, S. and A. B. Elam (2009) 'Transnational entrepreneurs' venture internationalization strategies: a practice theory approach', Entrepreneurship Theory and Practice, 33 (5), 1093-120, doi: 10.1111/j.1540-6520.2009.00336.x.

Vershinina, N. and Y. Rodionova (2011) 'Methodological issues in studying hidden populations operating in informal economy', International Journal of Sociology and Social Policy, 31 (11/12), 697-716, doi: 10.1108/01443331111177887.

Vershinina, N., R. Barrett and M. Meyer (2011) 'Forms of capital, intra-ethnic variation and Polish entrepreneurs', Work, Employment and Society, 25 (1), 101-17, doi: 10.1177/ 0950017010389241 .

Vertovec, S. (2001) 'Transnational challenges to the "new" multiculturalism', article to ASA Conference, University of Sussex, Brighton, 30 March-2 April, available at: www.trans comm.ox.ac.uk/working\%20papers/WPTC-2K-06\%20Vertovec.pdf.

Vertovec, S. (2007) 'Super-diversity and its implications', Ethnic and Racial Studies, 30 (6), 1024-54, doi: 10.1080/01419870701599465.

Vertovec, S. (2014) Super-diversity, London: Routledge.

Walther, O. (2012) 'Traders, agricultural entrepreneurs and the development of cross-border regions in West Africa', Entrepreneurship and Regional Development, 24 (3/4), 123-41, doi: 10.1080/08985626.2012.670909.

Wanner, C. (2005) 'Money, morality and new forms of exchange in postsocialist Ukraine', Ethnos, 70 (4), 515-37, doi: 10.1080/00141840500419782.

Wilding, R. (2006) "Virtual" intimacies? Families communicating across transnational contexts', Global Networks, 6 (2), 125-42, doi: 10.1111/j.1471-0374.2006.00137.x.

Williams, C. C. (2011) 'A critical evaluation of competing conceptualizations of informal employment: some lessons from England', Review of Social Economy, 69 (2), 211-37, doi: 10.1080/00346764.2010.502829.

Williams, C. C., J. Round and P. Rodgers (2013) The role of informal economies in the postSoviet world: the end of transition?, London: Routledge. 